\title{
Problems of Spanish [z], [s], [c] Sounds Pronunciation in Teaching Standards of the Spanish Language as a Foreign
}

\author{
Max D. Camacho Chavarria \\ $\mathrm{PhD}$, Professor, Moscow State Regional University \\ Yana V. Podoplelova \\ PhD, Professor, Russian University of Transport
}

\begin{abstract}
The present article considers linguistic norms and pronunciation standard of the Spanish language. It is shown that from the theoretical point of view the normative standards of dialectic variation of the Spanish language are considered. The problem of geographically diversified pronunciation standard of the Spanish consonant sounds is established. It is being noted that the unified standard language norm for all Spanish-speaking countries to be used in terms of teaching standards of the Spanish language as a foreign. The conclusion is made that knowledge of functioning particularities of the language system at cultural and social level is highly needed. In addition to that dialectic and accent variations of the Spanish language are to be taken into consideration
\end{abstract}

Key words: linguistic norm, language system, dialectic variation, The Spanish language rhythmic stress, phonological system.

JEL codes: Z-13.

\section{Introduction}

At the moment there are many linguistic studies on the topic of variations of the Spanish language in Spanish-speaking countries. Analyzing the concept of the linguistic norm of the Spanish language, first of all there is a question of phonological variability and the concept of a pronouncing norm, in which some forms can be recognized as normative, which entails the phenomenon of dialect variability. The preservation of the concept of linguistic prestige and literature - the linguistic norm - is the most important condition for the development of language as an integral language system.

When studying the issue of linguistic norms from the functional side, it seems impossible to distinguish the literary (Castilian) version of the Spanish language from the manifestation of its dialect features. In the process of identifying studies on territorial differences of dialects and 
regional deviations from the linguistic norm are being intensified. However, given the huge territorial extent and the large number of people who speak Spanish, the problem of establishing and recognizing a single standard norm is very relevant. According to the Royal Academy of the Spanish Language (RAE) - Spanish, by its nature, is a supranational language and is a set of diverse norms with a broad common basis. Thus, the problem arises of finding a single norm of the standard Spanish language, inherent in all regions of Spanish-speaking countries, which would guarantee full accessibility of understanding of the communicative situation, and allowing to speak about the Spanish language of twenty countries of the world as a single system [1].

In Russian science, the problem of teaching a literary or Castilian version of Spanish is not covered to the same extent as in foreign Spanish studies. Among the foreign scientists who studied the dialects of the Spanish language, one can note the collective work on the Andalusian dialect - A. Narbona Jimenez, R. Cano, R. Marillo Velarde Perez "The Spanish language of Andalusia", as well as the works of P. Henriques Urena, L. Flores, H. Montes Giraldo, L. Cuervo - scientists who studied the phenomenon of national dialects in the Spanish-speaking countries of Latin America. Montes Giraldo, a Colombian linguist, in his research notes two dialects in the Colombian national version of Spanish: coastal and intracontinental, based on the pronunciation of the phoneme /s/ in the position after vowel sounds, as well as the presence/absence of neutralization $/ \mathrm{r} /, / 1 /, / \mathrm{n} /$ in syllabic and dictionary endings. The analysis of the works of $\mathrm{T}$. Navarro Thomas devoted to the phonetic features of the Spanish language allows us to draw an intonational parallel in the dialects of the Spanish language in Latin America.

\section{Main part}

The Spanish language of South and Central America differs from the traditional Castilian Spanish in pronunciation features, many of which are also characteristic of the Andalusian dialect. This dialect had a strong influence on "Latin" Spanish, since Andalusians made up about $60 \%$ of emigrants who came to the new continent after its conquest [2]. In order to better understand the peculiarities of the development of the Latin American dialect of the Spanish language, it is advisable to consider in detail the individual consonants, which are designated by the letters "z", "c", "s", and their derived sounds on the example of various regions of Spain.

The letters "c" (ce), "z" (zeta) and "s" (ece) can represent different phonemes:

"Z" (zeta) is the twenty-ninth and last letter of the Spanish alphabet and the twenty-sixth in the international Latin order. The plural is "zetas" "zetas".

" $Z$ " represents two different consonant sounds according to the zones (see Table 1): 


\begin{tabular}{|l|l|l|c|c|}
\hline \multicolumn{1}{|c|}{ Spelling } & \multicolumn{1}{|c|}{ Sound } & Way of Pronunciation & Example & Pronunciation \\
\hline Z (Zeta) & deaf fricative preorsal & $\begin{array}{l}\text { Seseo } \\
\text { (whistling sound) }\end{array}$ & boot (zapato) & [sapato] \\
\hline Z (zeta) & deaf fricative & $\begin{array}{l}\text { Ceseo } \\
\text { (lisping sound) }\end{array}$ & boot (zapato) & [zapáto] \\
& interdental /z/ & & \\
\hline
\end{tabular}

Table 1. 'Z' sounds interpretation

" $\mathrm{C}$ " (ce) is the third letter of the Spanish alphabet and the international Latin order.

Represents three different consonant sounds (see Table 2):

\begin{tabular}{|c|c|c|c|c|}
\hline Spelling & Sound & Way of Pronunciation & Example & Pronunciation \\
\hline $\begin{array}{l}\mathrm{C} \\
\text { (ce) }\end{array}$ & $\begin{array}{l}\text { Before vowels "a", } \\
\text { “o", “u” and 'en' }\end{array}$ & $\begin{array}{l}\text { Deaf occlusive velar } \\
/ \mathrm{k} /\end{array}$ & $\begin{array}{l}\text { house (casa) } \\
\text { thing (cosa) } \\
\text { reasonable (cuerdo) }\end{array}$ & $\begin{array}{l}\text { [kása] } \\
{[\text { kósa] }} \\
\text { [kuérdo] }\end{array}$ \\
\hline $\begin{array}{l}\mathrm{C} \\
\text { (ce) }\end{array}$ & Before a consonant & $\begin{array}{l}\text { Deaf occlusive velar } \\
/ \mathrm{k} /\end{array}$ & $\begin{array}{l}\text { acne (acné)action } \\
\text { (acción) } \\
\text { skull (cráneo) }\end{array}$ & $\begin{array}{l}\text { [akné] } \\
\text { [aksión] } \\
\text { [kráneo] }\end{array}$ \\
\hline $\begin{array}{l}\mathrm{C} \\
\text { (ce) }\end{array}$ & At the end of the word & $\begin{array}{l}\text { Deaf occlusive } \\
\text { velar } / \mathrm{k} /\end{array}$ & $\begin{array}{l}\text { shelter (vivac) } \\
\text { Isaac (Isac) }\end{array}$ & $\begin{array}{l}\text { [bibák] } \\
\text { [Isák] }\end{array}$ \\
\hline
\end{tabular}

Table 2. 'C' sounds interpretation

According to the phonetic rules of Castilian Spanish, when pronouncing, one should avoid articulating this sound as interdental [ázto] to "act", [baztéria] to "bacteria", as well as its loss: [aféto] to "affection", [deféto] to "default" or its vocalization [direisión, direizión] to "address" (see Table 3).

\begin{tabular}{|l|l|l|l|c|}
\hline \multicolumn{1}{|c|}{ Spelling } & \multicolumn{1}{|c|}{ Sound } & \multicolumn{1}{c|}{$\begin{array}{c}\text { Way of } \\
\text { Pronunciation }\end{array}$} & Example & Pronunciation \\
\hline $\mathrm{c}(\mathrm{ce})$ & Before 'e' and before 'i' & $\begin{array}{l}\text { Ceceo }- \\
\text { deaf fricative } \\
\text { interdental }\end{array}$ & $\begin{array}{l}\text { supper (cena) } \\
\text { fatal (aciago) }\end{array}$ & $\begin{array}{l}\text { [céna] } \\
\text { [aciágo] }\end{array}$ \\
\hline
\end{tabular}

Table 3. Pronunciation of ' $c$ ' before ' $e$ ' and ' $i$ ' 
However, the letter " $\mathrm{z}$ " in the last syllable of derivatives of personal names can be replaced with "c" before the vowels "e" or "i". For instance, "El somocismo fue también un fenómeno económico". "Fue encarcelado por sus presuntos vínculos con el somozismo".

"S" is the twentieth letter of the Spanish alphabet and the nineteenth letter of the international Latin order. The plural is "eses" (see Table 4).

\begin{tabular}{|l|l|l|l|l|}
\hline \multicolumn{1}{|c|}{ Spelling } & \multicolumn{1}{c|}{ Sound } & \multicolumn{1}{c|}{$\begin{array}{c}\text { Way of } \\
\text { Pronunciation }\end{array}$} & Example & Pronunciation \\
\hline $\mathrm{s}(\mathrm{ece})$ & apico-alveolar & (ceceante) & house (casa) & [káza] \\
& & 'i’ lisping & sermon (sermón) & [zermón] \\
& & & person (persona) & [perzóna] \\
\hline
\end{tabular}

Table 4. Pronunciation of 's'

The above pronunciation variant is the most common in Spanish and dominates the entire country, with the exception of the regions of Andalusia and the Canary Islands, and also extends to the Spanish part of Latin America - in the Andes -Peru and Colombia.

"El ceceo - is a dialect phenomenon characteristic of some areas of southern Spain, which is the pronunciation of the letter "c" before the vowels "e" or "I" and "z" with a sound corresponding to the letter "s". For example, [serésa] instead of [cereza], [siérto] instead of [cierto], [sapáto] instead of [zapato] is the pronunciation of the letter "s" with a sound similar to the one corresponding to the letter "z". This phenomenon is also typical for most of the countries of the Spanish-speaking territory of Latin America, where one of the problems of the Spanish language is the lack of pronunciation of the true sound of "ceceo" in colloquial speech [3]. At the same time, the spelling rules of the classic Madrid royal style apply to the written version of the language. As a consequence of this pronunciation - spelling errors due to the lack of difference between the letters "s", "z" and "c".

According to Sanchez Mendes, a professor at the University of Neuchatel (Switzerland), "we can note a direct connection of this fact with the phenomenon of colonization of the New World - the discovery of America." At that time there were already two

There are two "geographical" ways to speak Spanish: one north of Castilla, which prevailed in Madrid, the other in Seville, in southern Spain. In Seville, the letters "z" and "c" were pronounced similarly to "s", and it was there that the main sea gate to America, the port of the Indies, was located. The relative majority of the first Spanish colonizers who arrived in America were from Seville and other parts of Andalusia: 37\% between 1493 and 1539, according to research by American historian Peter Boyd-Bauman [4]. 
In this regard, it should be remembered that in the seventeenth century the variety of dialects of the Iberian Peninsula was really rich, and there were few differences between the Castilian and Andalusian languages, with the exception of the dialect "ceceo", which is also characterized by the reduction of final vowels. Thus, the fusion of two different dialects with a clear predominance of the Andalusian language became the language of colonists of Castilian origin who went to conquer the territories of South and Central America. This historical fact confirms the importance of the contribution of Andalusians to the development of the Spanish language in Latin America. However, despite this, the following dialects of Spanish can also be found on the territory of the South American continent: Old Castilian, Leonese, Rioja, Navarre, Aragonese, Catalan and Baca. Undoubtedly, the linguistic consequences of the influence of the Andalusian dialect on the formation of the Spanish language of the Latin American region as a whole are noted.

Of course, in dialect conditions, the formal integrity, stability of nominative units is of no fundamental importance, giving way to detailed functional features that are clearly separated from each other. Since "variation is understood as a difference in reproduction, consisting in changing the sound composition of a structural unit of a language without losing its integrity, the framework of the latter is established within the boundaries of differences between individual uses of the word" [5, p. 56]. In formal phonetic and morphological variants of the word, "either semantic differentiation or additional changes in the sound shell leading to the destruction of material identity leads to a violation of lexical identity" [5, p. 78].

It is also necessary to take into account the variations of dialects in the issue of teaching Spanish as a foreign language. Referring to the principles of the Pan-European System of Foreign Language Proficiency Levels (MCER), it is important to note that the teaching of Spanish phonetics as a comprehensive knowledge system has a number of features at each of the levels of language proficiency, which is directly related to the fact of the presence of territorial dialects. At the elementary level, special attention should be paid to the correct pronunciation of sounds, at the threshold and advanced level - the phonetic implementation of Spanish phonemes, at the level of professional proficiency there are no segmental elements.

\section{Conclusion}

The study of articulatory features of vowels and consonants of the Spanish language is characteristic of the elementary level. Features of semantic intonation groups of the Spanish language, as well as the study of the functional capabilities of intonation means as a consequence of the expression of communicative organization of utterance is the basic knowledge that must 
be mastered and consolidated in practice by students.

The structure of the intermediate level includes understanding and identification of sound variants - mastering the full spectrum of allophonic content, taking into account contextual and positional variants. Special attention can be paid to the study of the role of the melodic component and the phonetic implementation of phrasal stress.

Moreover, the fact that there are many variations of dialects and accents of the Spanish language complicates the understanding and meaning of some sounds, which entails the problem of misinterpretation of the norms and rules of pronunciation in Spanish, as well as linguistically literate display of sounds. However, it is important to understand that in order to master a foreign language in full at each of the levels, it is necessary to take into account the socio-cultural component - which allows you to study and understand the peculiarities of the functioning of the language system at both cultural and social levels [6]. The formation and development of the components of socio-cultural competence allows students to learn to adapt to the language environment faster through the development of communication skills, which means that they can correctly accept and interpret the sounds of the foreign language being studied.

Based on the factors of geographical differentiation, it should be remembered that dialects have "great freedom of phonomorphological means to convey a particular meaning, the resulting variants of words form a complex chain, the individual links of which are sometimes very close to each other in sound and difficult to distinguish in meaning" [7, p. 25].

In this regard, the main reason explaining the presence of a wide range of variations is the oral form of the existence of dialects in various geographical locations. And, as a result, there is an abundance of geographical names and differences in pronunciation, different degrees of familiarity of dialect speakers with names, terminology, their different perceptions, the need for a more accurate description of the object. Consequently, the formal variation of words and sounds, being an immanent property of any kind of language, including the literary form, with its modified norms, written traditions, differs at the level of oral speech of each of the dialects. 


\section{References}

1. Murashkina O.V. Problemi v obuchenii russkogovoryashikh studentov normativnomu proiznosheniyu ispanskogo yazyka. [Elektronnyi resurs]. // Yazykitekst. 2018. Tom 5. № 3. S. 62-66.

2. Juan Pedro Sánchez Méndez. Historia de la lengua española en América. Valencia: Tirant loBlanch, 2003, P. 494

3. Garcia Mouton P., Lenguas y dialectos de España. - Madrid : Arco Libros, 1994 (Cuadernosde Lengua Española). - P. 235

4. Boyd-Bowman Peter. Indice Geobiografico de Mas de 56 Mil Pobladores de La America Hispanica, I:1493-1519, Mexico: Instituto de investigaciones históricas UNAM y Fondo de Culturaeconómica, 1985, P. 170

5. Barshak M.A. Ispanskiy yazyk: Prakticheskaya fonetika: uchebnik dlya institutov I fakultetovinostrannykh yazyjov/ M.A. Barshak, M.: Vyshaya shkola, 1989. $223 \mathrm{~s}$.

6. Hernández Alonso, C. (2001): “QQué norma enseñar?”Actas electrónicas del II Congreso Internacional de la Lengua Española, «El españolen la Sociedad de la Información». Valladolid, P. 16-19. URL:

https://cvc.cervantes.es/obref/congresos/valladolid/ponencias/unidad_diversidad_del_esp anol/1_la_norma_hispanica/hernandez_c.htm

7. Karpov N.P. Phonetika ispanskogo yazika: teoreticheskyi kurs dlya ins-tov y fak.inostr.yaz./ N.P. Karpov. - M.: Vyshayashkola, 1969. 232 s.

8. Juan Romeu Fernández, Lo que el español esconde: Todo lo que no sabes que estás diciendocuando hablas. Larousse editorial S.L., Barcelona 2017, P. 25. 